\title{
Viking Games and Saami Pastimes: Making Balls of Fomitopsis betulina
}

\author{
Ingvar Svanberg ${ }^{1 *}$ and Isak Lidström² \\ ${ }^{1}$ Institute for Russian and Eurasian Studies, Uppsala University, Sweden. ${ }^{2}$ Department of Sport Science, Malmö University, \\ Sweden. \\ *ingvar.svanberg@ires.uu.se
}

\begin{abstract}
Ethnomycology is the study of the bio-cultural aspects of human-fungal interactions. This article discusses the involvement of the bracket fungus Fomitopsis betulina within the material culture of traditional games. With a particular focus on the Nordic countries, the aim is to review and analyze the use of simple balls made of bracket fungi. We argue that the fungi ball can be considered the precursor of the rubber (and the gutta-percha) ball. Moreover, the replacement of fungi balls with rubber balls marks, to a certain extent, a temporal transition from traditional folk games with roots in preindustrial society to modern sports in which balls and other equipment received a more standardized shape.
\end{abstract}

Received March 19, 2019

OPEN ӘACCESS

Accepted May 31, 2019

Published November 5, 2019

DOI 10.14237/ebl.10.1.2019.1565

Keywords Bio-cultural domains; Bracket fungi; Childlore; Cultural context; Ethnomycology; Ball games; Traditional games

Copyright (c) 2019 by the author(s) licensee Society of Ethnobiology. This is an open-access article distributed under the terms of the Creative Commons Attribution-NonCommercial 4.0 International Public License (https://creativecommons.org/licenses/by-nc/4.0), which permits non-commercial use, distribution, and reproduction in any medium, provided the original author and source are credited.

\section{Introduction}

Play elements in a culture are important for human beings, as has been pointed out by the Dutch historian Johan Huizinga (1949). In pre-industrial society, many activities required an intimate familiarity with local biota (Lévi-Strauss 1962). This is also reflected in the material culture connected with traditional games. Traditional games involved the use of implements made of local biological resources. Today, most of the time-honored knowledge about local biota is losing ground in contemporary urban and post-industrial societies like those in Scandinavia. Nowadays, there is little demand for this kind of knowledge. However, children's play with plants and other biological organisms sometimes reveals the customs and practices of older times (Anderson 2000; Luczaj and Kujawska 2012; Svanberg 2001, 2007; Svanberg et al. 2011; Zarger and Stepp 2004).

Balls (Old Norse knottr) were used in violent ball games by adults during the Viking age and early medieval times. These balls seem to have been made of wood or other hard materials (Bjarnarsson 1905; Götlind 1934). However, children probably used softer materials, even though their games could also be violent (Høeg 1971). The Old Norse word for fungus (bracket) was seppr, which was also synonymous for the balls used in games (Matras 1955). In the late thirteenth century, Old Norse prose translations of various "chansons de geste" about Charlemagne and his twelve peers, known as Karlmagnús saga ok kappa hans, mention a soft ball (seppr) which was a ball that was soft enough to grip and throw (Bjarnarsson 1905; Unger 1860). In several Norse medieval ballads, the word sopp was used for a ball in various ball games (Bugge 1858; Landstad 1853).

In 1973 the Saami author Sara Ranta-Rönnlund (1903-1979), who comes from a conservative Laestadian Christian reindeer herding family of Leaváš čearru in the province of Norrbotten, wrote about outdoor games that amused the Saami children during her childhood. Many of these games were considered sins by her Laestadian parents. One such game was a kind of ball game, in which they used large, soft bracket fungi that grow on the trunks of mountain birch trees (Betula pubescens var. pumila). The bracket was shaped with a knife (Ranta-Rönnlund 1973).

The ball used by Sara and other Saami children was made from the birch bracket or birch conk, Fomitopsis betulina (Syn. Piptoporus betulinus). Making such balls was a practice among the Norse people, 


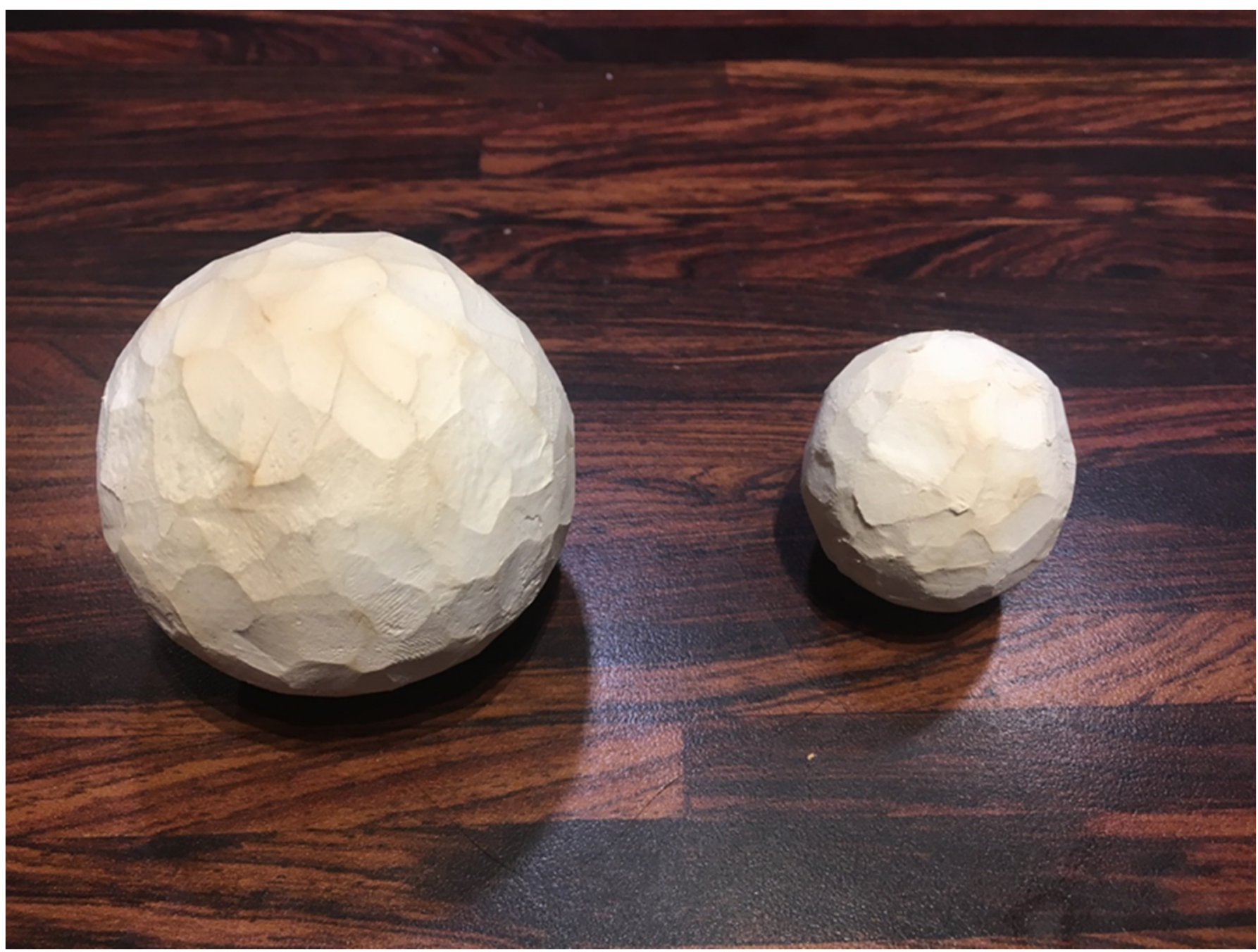

Figure 1 Freshly made balls of Fomitopsis betulina (Photo by Isak Lidström).

Nordic (Swedish, Norwegian) peasants and the Saami in Sápmi, probably occurring as early as the Viking age (Liestøl 1919; Matras 1955). They shaped the brackets into balls by cutting them with a knife. Occasionally, such balls are still made (Høeg 1974; Kjellström 2000; Klintberg 1998; Olsson 2009).

\section{Methods and Objectives}

Ethnomycology is the study of the bio-cultural aspects of human-fungal interactions (YaminPasternak 2011). Research in historical folk mycology and folk knowledge can provide us with information about little known practices in the past (Svanberg 2007; Medeiros 2016).

Data found in archives and in scattered notes in older literature are invaluable sources when it comes to mapping the diversity of the pre-industrial local people's relationship to the biota in the eighteenth and nineteenth centuries (Svanberg 2018). This study is focused on the use of brackets in traditional games. We will also briefly review other uses of some bracket fungi on the Scandinavian Peninsula.

For this research, we are using a qualitative method where ethnographic description plays an important role. There are several kinds of sources: ethnological monographs, folk-life records, mycological literature, philological studies, and topographic literature (Svanberg 2010). With the help of ethnographic records in printed sources, dictionaries, and records in the folklore archives in Sweden (located in Härnösand, Stockholm, and Uppsala), this article sets out to review and analyze the cultural context and use of simple balls made of bracket fungi. In addition, other kinds of homemade 
balls are briefly considered. We will also describe the ball games wherein such balls were used.

\section{Bracket Fungi in the Nordic Folk Biology}

Bracket fungi, also called shell fungi or polypores, are a distinctive category of fungi, which were important in Scandinavian pre-industrial society, sometimes even later. It constitutes a polyphyletic group that was long perceived as a fungus family (Polyporaceae). However, recent molecular studies have resulted in its division into several different orders (Hibbett et al. 2007).

Commonly bracket fungi parasitize tree trunks and branches, although some are terrestrial and form mycorrhiza with trees. An example of the terrestrial form is the forest lamb (Albatrellus ovinus) which is nowadays an edible mushroom appreciated in Sweden (Svanberg 2018). A few bracket fungi taxa were by tradition culturally salient in northern Scandinavia (Høeg 1974; Svanberg 2018). Polypores have been used for health-related, technical and other purposes, including balls in children's games. Some species are common and widely distributed in boreal areas of the northern hemisphere (Jaederfeldt 2004).

The use of some of the taxa, such as birch conk, F. betulina, and tinder bracket, Fomes fomentarius, is known to occur across vast areas (Allen and Hatfield 2004) and since ancient times. Pieces of fruiting bodies from both of those taxa were, for instance, carried by the mummified body known as Ötzi the Iceman who lived 5300 years ago and was discovered in the Ötztal Alps (Alpi Venoste) on the border between Austria and Italy (Peintner and Pöder 2000; Tunón and Svanberg 1999).

The fruiting body of $F$. betulina has a rubbery texture which becomes corky with age. Ethnobiological data from the pre-industrial Scandinavian Peninsula indicates that this fungus has had various medical uses. For instance, charcoal produced from it has been used as an antiseptic agent (Høeg 1974; Klintberg 1998; Peintner and Pöder 2000; Svanberg 2018). In eighteenth-century Västergötland, it was used in that province's folk veterinary medicine against a bacterial disease (locally known as rödsot) in sheep (Svanberg 2018). In addition, the data show that this fungus has been used for nonmedical purposes, such as protecting metal blades from rust, sharpening razors, and as toys, cork, or pin cushions (Fries 1864; Linnaeus 1755; Retzius 1806; IFOS: ULMA 28641). In Flora Svecica, Linnaeus

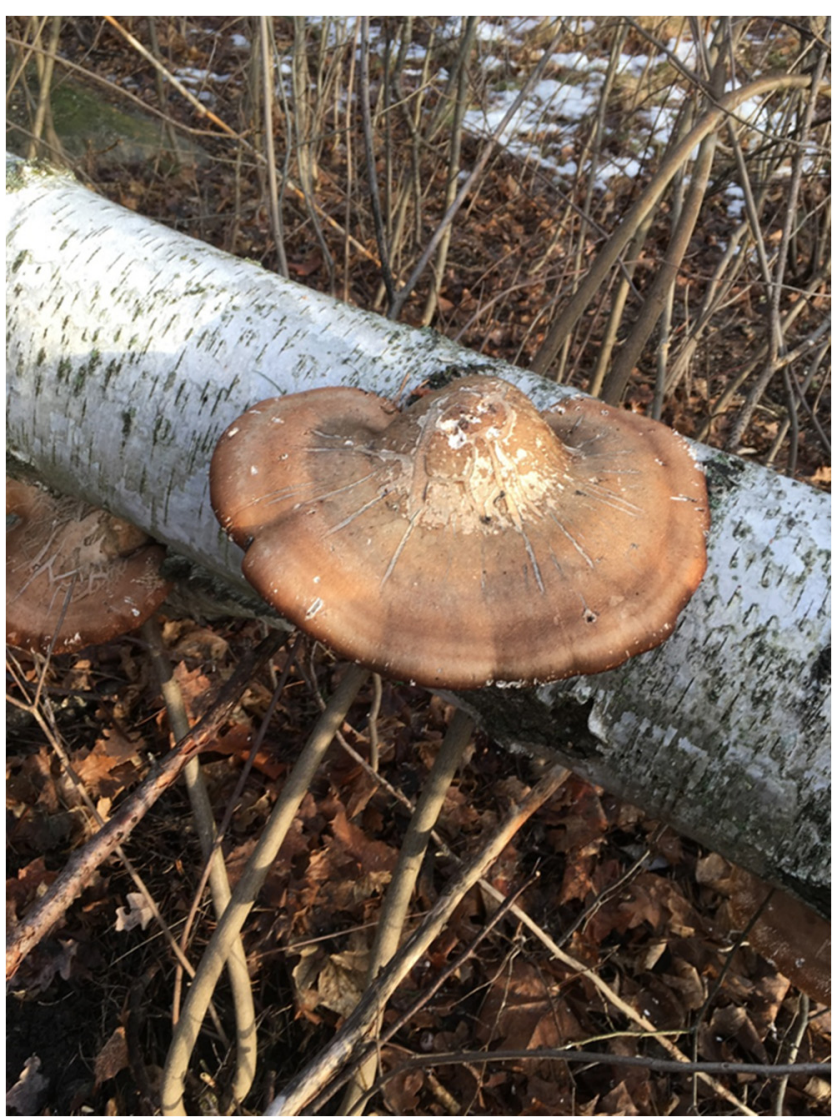

Figure 2 Birch conk, Fomitopsis betulina (Photo by Isak Lidström, 2019).

noted that the birch conk was used instead of cork to stopper bottles (Linnaeus 1755; Retzius 1806). According to Rothof (1762), well-dried birch conk could be used as floats on fishing nets and fishing lines. In nineteenth-century Småland, the soft part of the fungus was cut into pieces and used by children in the village schools to erase what they wrote on their slates (Klintberg 1998). The fruit body could also be shaped to make dolls' heads (Olsson 2009).

Tinder bracket, Fomes fomentarius, primarily a Holarctic taxon, is found all over Europe, North Africa (including the Canary Islands), Asia, and North America. It has been widely used across the northern hemisphere to make amadou, a kind of tinder (Manninen 1933; Harding 2008). The species' common name accurately reflects the historic role of the true tinder fungus in making and transporting fire. Among the Saami, it was also burned on the skin in the manner of moxibustion (Steen 1961). In the collection of the Royal Armoury (Livrustkammaren), Stockholm, there are a few textiles made of F. 
fomentarius, as well as a jacket, a cap, and a bag. It has also been used as a styptic by surgeons, barbers, and dentists (Roussel et al. 2002; Svanberg 2018). Other taxa used by the locals in Scandinavia are false tinder conk, Phellinus igniarius, used for making tinder (Allen and Hatfield 2004; Linnaeus 1737; Svanberg 2018). Its smoke was regarded by local users as effective against mosquitoes (Høeg 1974; Linnaeus 1737). Scented bracket fungus, Haploporus odorus, has a fragrant aniselike scent which persists even after drying. It has been used by peasants in northern Sweden to flavor snuff, bread, brown cheese, and rice pudding (Svanberg 2018). The male Saami youth used it as fragrance (Linnaeus 1737), while the peasants in northern Sweden used it for its pleasant scent in storage chests (Svanberg 2018).

\section{Balls and Ball Games}

Ball games have been played by humans since ancient times. Classical literature, iconographic evidence, and ethnographic descriptions recount a great variety of ball games from various parts of the world (Culin 1907; Nordenskiöld 1912; O’Sullivan 2012). Several ball games are mentioned in ancient Greek and Roman literature, sometimes even with detailed descriptions of the rules. Among these pastimes, the physically demanding ball game harpastum, in which two competing teams on a divided field struggled to keep the ball on their side, was most likely inherited by the Romans from the Greeks (Harris 1972).

The ancient Nordic peoples also played ball games. One of the Golden Horns of Gallehus, dated from fifth-century Denmark, depicts a man throwing a ball. Several mentions of knattleikr (which literally means "ball game") in the Icelandic saga literature confirm that ball games occurred frequently even during the Viking age in Scandinavia (Martin 2003; Thurber 2015). Like the Vikings, these games could get violent. The third chapter of the legendary saga (fornaldarsögur) about mythical kings, Bósa saga ok Herrauðs, written around 1300, mentioned "soppleikr." However, from the context one can assume that the ball was not soft and the game was not for weaklings:

"There was one time when the king's men had a ball game (at hirdin hafoi soppleik), and people were playing with much energy, and the action came to Bosi. He responded roughly, and the arm of one of the king's men was dislocated. The next day he broke the foot of another. On the third day two men went after him and many of them shoved him. He struck the eye out of one of them with the ball (ló hann pá augat ór einum med soppinum), and felled another and broke his neck" (Trans. George L. Hardman in Hardman 2011).

Humans have long found enjoyment in throwing, kicking, hitting, catching, and bouncing a ball, this simple piece of technology. Before the introduction of rubber produced by the rubber tree (Hevea brasiliensis) from South America, balls were made of wood, leather, animal hide, and swine-bladders (and other domestic mammal's bladders). From the 1840s, natural rubber became the main raw material for making balls, although among the Scandinavian peasantry and the Saami the practice of making simple homemade balls survived until the twentieth century (Bjurman 1980; Kjellström 2000; Lönnqvist 1970; Vold Halvorsen 1983).

The traditional manufacture of balls has varied from place to place. One common method was to make a cover by sewing together a couple of pieces of leather. The cover was then stuffed with various materials such as cloth, rags, cow- or horsehair, pigs' bristles and star moss (Tortula ruralis) (Brøndegaard 1978; Knudsen 1922; Lidström 2017; Tillhagen and Dencker 1949). Several travelers reported watching ball games in action. In 1673 the German-Swedish scholar Johannes Schefferus described a game played by the Saami of northern Scandinavia (Sápmi) with a ball as "big as a fist, made of leather, and stuffed with hay" in his comprehensive work Lapponia (The History of Lapland) (Mehl 1949; Schefferus 1673). Italian explorer Guiseppe Acerbi witnessed how the Saami played a game "with a leathern ball stuffed hard" during his travel to the North Cape in the late eighteenth century (Acerbi 1802). Norwegian priest Knud Leem described a Saami ball game saying that the ball was "covered with hide and stuffed with hair, straw, rags, or the like" in his old but informative account of the Saami people in Finnmark (Leem 1767; Mehl 1949). The Saami reindeer herder Anta Pirak remembered balls stuffed with sand (Pirak 1933).

Other documents mention other ways to make balls. Until recently, many balls in Scandanavian countries were made by wrapping wool thread around a cork or other hard material, such as stone, lead, or wood (Falk Ytter 1868; Knudsen 1922; Lönnqvist 1970; Tillhagen and Dencker 1949; Wessman 1962). A different way to make balls occurred after the slaughter of cattle. These balls were made by scraping vertebrae into round shapes and subsequently boiling 


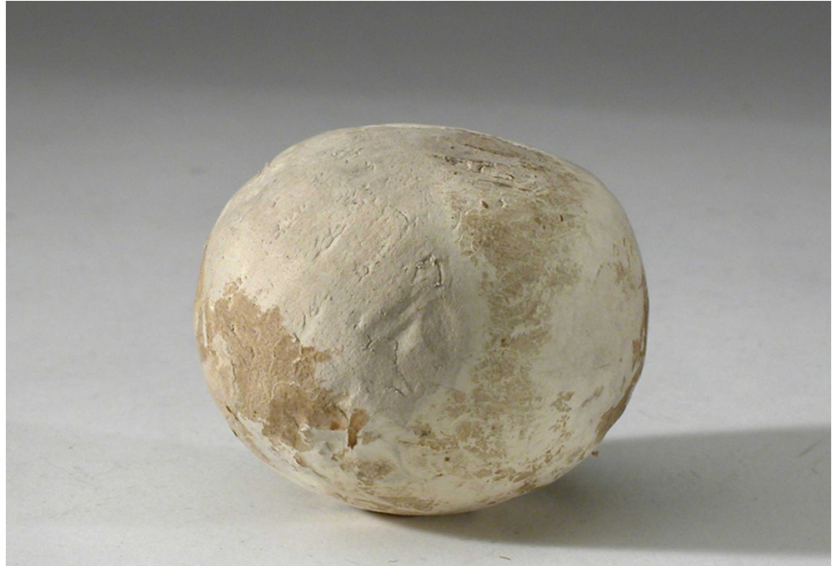

Figure $3 \mathrm{~A}$ nineteenth century ball made of birch conk at Mattisudden's Saami handicraft school. Nordic Museum Collection NM 42852a (Photo courtesy of the Nordic Museum, Stockholm).

them in lye in order to make them soft (NM: EU 10381).

However, in some games, especially the traditional bat-and-ball games, a hard core was necessary for the ball to be hit high and far. This required a somewhat different manufacture as is described in an account from the Danish island of Mors: the core was made of cow hair soaked in urine, thereafter heated in water and coated with tar. Finally, a cover could be embroidered around the core (Knudsen 1922). Balls of this sort were not only objects for play but also small pieces of artwork, as is evident from the beautiful embroidery with patterns in different colors (Knudsen 1922).

Balls made of bracket fungi seem to be exclusive to Scandinavia in Europe, and are known from Norwegian, Swedish, and Saami ball games (Høeg 1974; Manker 1947; Kjellström 2000). According to ethnographer Toivio Immanuel Itkonen (1941), the Saami in Inari in northern Finland made balls of birch fungi, which they boiled in ash lye, after which they were formed into balls that became very elastic.

Ethnobotanist Ove Arbo Høeg gives several examples from twentieth century Norway of how people, especially boys, made balls of birch brackets to play with. During World War II when there was a shortage of rubber balls, they used brackets instead. If the bracket balls became hard and dry, they soaked them (Høeg 1974). There are occasional records from Denmark that boys played soccer with a bracket ball during World War II (Brøndegaard 1978). There are

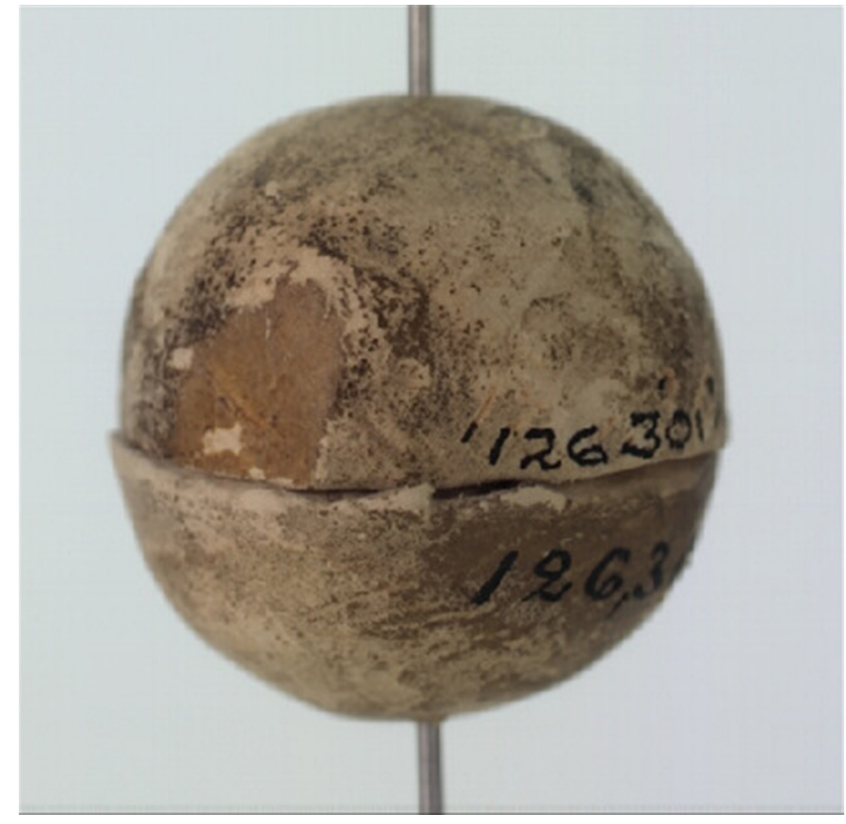

Figure 4 A ball made of birch conk used in 1898 by Finnish-speaking children in the area between Haparanda and Piteå in northern Sweden (Photo courtesy of the Nordic Museum, Stockholm).

also notes about the use of birch brackets for making balls among the Hungarians in Transylvania (Papp et al. 2017), as well as records from indigenous people in North America. For instance in Canada, the Stól:ō and Haisla of British Columbia used brackets in various ball games (Turner 1998).

\section{Games Using Bracket-Balls}

A common game among the Saami who lived around the Lule River in the first half of the nineteenth century was simply called "bat ball" (rättot). Few details of this game have been left to posterity, but in her 1918 published dissertation, Sigrid Drake mentions that the ball was made of a white bracket (svappa) and covered with chamois. A bat (ratto-muor), and a goal (radja) were used in the game (Drake 1918), indicating that the pastime was a variant of a game usually known in the Scandinavian countries as "longball" (Danish: langbold; Swedish: längboll), an old and widespread traditional bat-and-ball game similar to American baseball. Many variants of longball have gone by different names, such as Söt och sur ("Sweet and sour") and Tre slag och ränna ("Three strikes and run") in Sweden. However, some basic principles of the game can be mentioned. The playing field is in the shape of a rectangle, approximately 30 to 50 meters long, in which the short sides mark the borders that 
distinguish two bases-the home base and the running base-from the fielding area. Two teams position themselves at the bases, the batting team at the home base and the fielding team at the running base. The aim of the fielding team is to win the position of batting team, while the aim of the batting team is to defend its position at home base. The game starts when a pitcher from the fielding team tosses the ball to a batsman of the batting team who, after a successful hit, starts running from the home base to the running base. If someone from the fielding team manages to catch the ball before it touches the ground, the teams switch bases. At both bases, the batsman and his team members are considered safe, but as soon as they run on the field between the two bases, they risk being "burned": in other words, hit with the ball by any member of the fielding team. As soon as this happens, the teams switch sides (Götlind 1934; Hellspong 2000; Tillhagen and Dencker 1949).

Although balls made of leather, cork, and wool thread have been most popular with people playing longball, birch conk was nonetheless used in large parts of Sweden from the province of Lapland in the north (Drake 1918), to Björkvik parish in Södermanland (NM: EU 32006), and Stenestad parish in Skåne province, southern Sweden (NM: EU 7579).

A variant of longball was recorded by Erik Lehmann from Hallingeberg parish, Småland province. In this game called Spele boll (play ball), the ball was made either of rags wrapped in cloth or of soft birch conk (NM: EU 10714). In a record from Frändefors parish, Dalsland province, informant Anders Jansson describes the game under the name Sla boll (Bat ball) and states that the best balls were made of fungi that grew on birch or Swedish whitebeam, Sorbus intermedia (NM: EU 20893).

Playing longball was a common and very old practice in the pre-industrial society of Nordic countries. Although the word "longball" was unfamiliar at the time, all the accounts of Saami ball games from the seventeenth and eighteenth centuries cited above are most likely variants of the game. This is true at least regarding the account provided by the Norwegian priest Knud Leem (1767). The games mentioned by Schefferus (1673) and Acerbi (1802) seem simpler since no base running procedure is provided in the descriptions. Previously, it was often argued that longball was a game of Nordic origin (Balck 1886; Maigaard 1941). However, such a claim seems obsolete as it is obvious that the game in

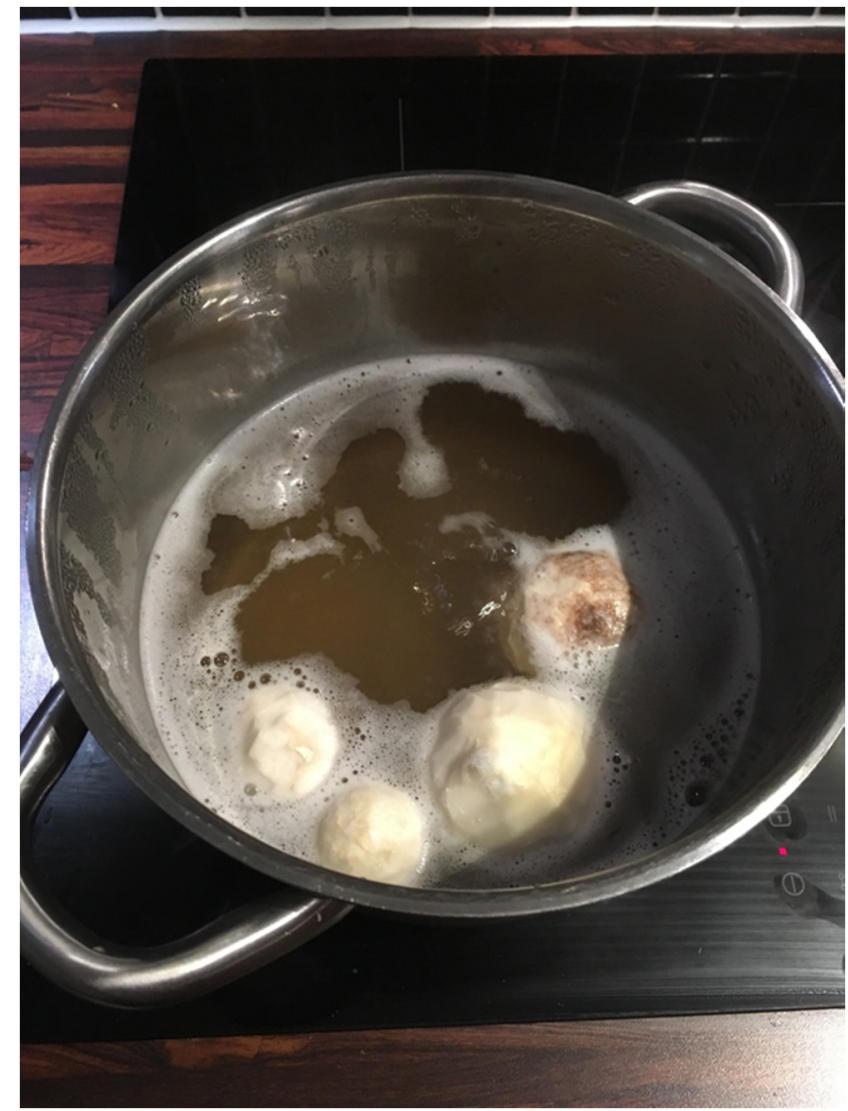

Figure 5 The birch conk balls are boiled in ash lye (Photo by Isak Lidström, 2019).

different variants and under different names has occurred in large parts of Europe and outside, even back in antiquity (Craven 1978; DeHass and Droulias 2010; Gini 1939; Mendner 1956; Møller 1997; Riordan 1986/1987).

In 1930 P. M. Lundin recorded a very old and rare ball game from an old man from the Swedish parish of Laxviken, Jämtland province. The participants were divided into two teams and stood in two lines, facing each other. A pitcher tossed the ball to a batsman of his own team. The batsman was to strike the ball as hard as possible against the other team so that it could break through the opponents' line. The other team's job was to defend their line, and if the batsman could rebound the ball, so much the better. Balls made of birch conk were particularly useful in this game, since they were hard and bounced very well (NM: EU 866).

The birch conk's elasticity provided an obvious advantage in games where the ball was supposed to bounce. A record describing the common folk game 
bollstå stated that the ball was thrown at a wall and needed to bounce back as far as possible: for this, a birch conk core was wrapped with cloth and covered with wool thread (NM: M 7548). The previously mentioned game, described by the Saami author Sara Ranta-Rönnlund, also underlines how unsurpassed the birch conk was if the objective was to make a ball with bounce. The game was simple but nevertheless required certain skills. With a stick of the right size, the ball could be hit straight up in the air. The aim was then to keep it in the air with additional new hits (Ranta-Rönnlund 1973).

In 1915 ethnologist Levi Johansson recorded the outdoor game peta boll from his informant Anna Kristina Berglund in the village of Åkrogen, Graninge parish, Angermanland province. Mrs. Berglund as a child used balls made of fresh birch conk to play the game (Murberget: LMV-M 265). The game peta boll $i$ grop was a very common folk game in the preindustrial society. In the center of the play area was a pit in the ground around which several smaller holes were dug in a circle-one hole fewer than the number of participants. All participants were equipped with a wooden stick. One participant was selected as the ball player, whose aim was to get the ball into the pit. The other participants - the defenders-wanted to prevent this from happening. However, they were supposed to defend not only the pit at center of the playing field, but each of them also protected one of the smaller holes by keeping the end of their stick in it. When a defender tried to hit the ball with his stick, he also risked being deprived of his own hole, if the ball player managed to put his own stick into it. When this occurred, positions were changed so that the defender who lost his hole became the new ball player. This also happened if the player managed to strike the ball and hit (bränna) any defender with it (Götlind 1934; Hellspong 2000; Tillhagen and Dencker 1949).

In the mid-nineteenth century, ethnologist and teacher Pehr Arvid Säve from the Swedish island of Gotland recorded the same game from his informant Catharina B. Östman. The game was called laika bränn-baill (which should not be confused with the very popular bat-and-ball game brännboll which is still played in Sweden today). Laika bränn-båll was played with a ball made of birch conk (Säve 1948; see also NM: EU 2648). Another record describing this game also mentions a ball of birch conk, called vitsyppa in the local vernacular (Swedish province of Jämtland).
According to informant Per Persson from Grimnäs parish, the material from the birch conk could easily be kneaded to form a ball, which after drying became durable and pleasant to handle (NM: EU 41254). Evidence of balls made of birch conks for playing this game is also known from the Swedish provinces of Västergötland (NM: EU 2661) and Småland (NM: EU 2954). After studying records describing the game of peta boll $i$ grop, it is clear that the materials used to make the ball varied greatly, and birch conk was not as common as a lathed ball of wood. Simpler materials could also be used, such as a stone (Hellspong 2000) or a potato (NM: IFGH 2810-1932-1863).

As a traditional folk game, peta boll $i$ grop was widespread in various parts of Europe (Brewster 1957; Hellspong 2000; Knudsen 1932). The name of the game varied not only from country to country but also from village to village. Often the name was a description of the practice, for instance, the name peta boll $i$ grop means literally "poke the ball into the pit". However, in several accounts from different parts of Europe, the ball symbolized a swine and the player represented the swineherd. In the 1920s in Denmark the game was still known as So $i$ hul, which literary means "Sow in hole" (Knudsen 1932; Møller 1997). Among the Swedish-speaking population on the Estonian island of Naissaar/Nuckö, the game was called Svin-späl and the task of the ball player was to ker svine ("drive the swine") (IFOS: ULMA 19435). Brewster (1957) provides several examples of this swine symbolism from Russia, Poland and Eastern Europe.

\section{Conclusion}

Our impression is that fungi balls were not used as commonly in traditional ball games of the Nordic countries as leather balls stuffed with materials such as corks, rags, hay, or cloth. However, as a result of this overview, it is clear that the birch bracket had particular benefits, which other materials lacked. In simpler games, which required a ball with a lot of bounce, the elastic property of the birch conk was very useful. In more advanced games, such as longball, more effort was put into the manufacture of the ball, which could include sewing a leather case, stuffing the ball, and even embroidering the case with patterns in different colors.

A characteristic of balls made of birch conk was that they were easy to make: the only tool needed was a knife. In the vast majority of the accounts studied, the balls consisted of birch conk only. Some accounts, 
however, reveal that the balls could be covered with a case of leather (Drake 1918) or that the fungi functioned only as a core to produce a ball with bounce (NM: M 7548).

Another impression is that fungi balls belonged to a traditional practice of folk games, in which participants manufactured their own equipment for use in games (Hellspong 1990). The fungi ball can thereby be considered the precursor of the rubber (and the gutta-percha) ball, which was not homemade but produced by specialists and obtained by those who used it (cf. NM: EU 32006). A record from Dalsland province in Sweden states that as soon as rubber balls could be purchased, fungi balls were no longer used (NM: EU 20893). It is interesting to note, however, that in times of commodity crisis, such as during the World Wars, people still knew how to make fungi balls as substitutes for leather or rubber balls, even in the sport of soccer (Høeg 1974). To conclude, the replacement of fungi balls with rubber balls marks to a certain extent a temporal transition from traditional folk games with roots in the preindustrial society, to modern sports in which balls and other equipment received a somewhat standardized shape.

\section{Acknowledgements}

For improving our English, we are much obliged to Ms. Karen Magnuson Beil, Harwich, MA.

\section{Declarations}

Permissions: None declared.

Sources of funding: None declared.

Conflicts of Interest: None declared.

\section{References Cited}

Acerbi, G. 1802. Travels through Sweden, Finland, and Lapland to the North Cape 2. Joseph Mawman, London.

Allen, D. E., and G. Hatfield. 2004. Medicinal Plants in Folk Tradition: An Ethnobotany of Britain and Ireland. Timber Press, Portland, OR.

Anderson, M. 2000. Saami Children and Traditional Knowledge. In Ecological Knowledge in the North: Studies in Ethnobiology, edited by I. Svanberg and H. Tunón, pp. 55-65. Swedish Biodiversity Centre, Uppsala, Sweden.

Balck, V. 1886. Illustrerad Idrottsbok: Handledning i olika Grenar af Idrott och Lekar 1. C. E. Fritzes K.

Hofbokhandel, Stockholm.
Bjarnarson, B. 1905. Nordboernes legemlige Uddannelse $i$ Oldtiden. Priors Hofboghandel, København.

Bjurman, E. L. 1980. En Fotboll av Hopskrynklade Tidningar. Nordiska Museets Insamling av Hemgjorda Leksaker. Rig 63:81-83.

Block, D. 2005. Baseball Before We Knew It. A Search for the Roots of the Game. University of Nebraska Press, Lincoln.

Brewster, P. G. 1957. Some Games from Czechoslovakia. Southern Folklore Quarterly 21:165174.

Brøndegaard, V. J. 1978. Folk og Flora: Dansk Etnobotanik 1. Rosenkilde og Bagger, København.

Bugge, S. 1858. Gamle Norske Folkeviser. Feilberg \& Landmark, Kristiania.

Culin, S. 1907. Games of the North American Indians. Government Printing Office, Washington.

Cumo, C. 2013. Rubber. In Encyclopedia of Cultivated Plants 3, edited by C. Cumo. pp. 900-909. ABCCLIO, Santa Barbara, CA.

Craven, D. H. 1978. The Evolution of Major Games. University of Stellenbosch, Stellenbosch.

Dehass, M., and A. Droulias 2010. Aleut Baseball: Cultural Creation and Innovation through a Sporting Event. Études/Inuit/Studies 34:21-37. DOI:10.7202/1003845ar.

Drake, S. 1918. Västerbottenslapparna under Förra Hälften av 1800-talet. Almqvist \& Wiksell, Uppsala.

Falk Ytter, O. V. 1868. Kroppsöfningar och Lekar. Abr. Bohlin, Örebro.

Gini, C. 1939. Rural Ritual Games in Libya (Berber Baseball and Shinny). Rural Sociology 4:283-299.

Götlind, J. 1934. Gamla Svenska Idrottslekar. Bonnier, Stockholm.

Hardman, G. L. 2011. The Saga of Bosi and Herraud. In The Complete Fornaldarsögur Nordulanda. Legendary Sagas of the Northland in English Translation. www.germanicmythology.com/ FORNALDARSAGAS/BosaSagaHardman.html

Harris, H. A. 1972. Sport in Greece and Rome. Thames and Hudson, London.

Hellspong, M. 1990. Slå Trilla. En Lek på Gränsen Mellan Folklig och Modern Idrott. Rig 73:1-16.

Hellspong, M. 2000. Den Folkliga Idrotten: Studier i det Svenska Bondesambällets Idrotter och Fysiska Lekar under 1700- och 1800-talen. Nordiska museets förlag, Stockholm. 
Hibbet D. S., M. Binder, J. F. Bischoff, P. F. Cannon, O . E. Eriksson, S. Huhndorf, T. James, P. M. Kirk, R. Lücking, H. T. Lumbsch, F. Lutsoni, P. B. Matheny, D. J. McLaughin, M. J Powell, S. Redhead, C. L. Schoch, J. W. Spatafora, J. A. Stalpers, R. Vilgalys, M. C. Aime, A. Aprot, R. Bauer, D. Begerowp, G. L. Bennyq, L. A. Castrebury, P. W. Crous, Y-C. Dai, W. Gams, Walter Gams, D. M. Geiser, G. W. Griffith, D. L. Hawksworth. G. Hestmark, K. Hosaka. R. A. Humber, K. D. Hyde, J. E. Ironside, C. P. Kurtzman, K-H. Larsson, R. Lichtwardt, J. Longcore, J. Miądlikowska, A. Miller, J-M. Moncalvo, S. Mozley-Standridge, F. Oberwinkler, E. Parmasto, V. Reeb, J. D. Rogers, C. Roux, L. Ryvarden, J. P. Sampaio, A. Schüssler, J. Sugiyama, R.G. Thorn, L. Tibell, W. A. Untereiner, C. Walker, Z. Wang, A. Weir, M. Weiss, M.M. White, K. Winke, Y-J. Yao, N. Zhang. 2007. A Higher-Level Phylogenetic Classification of the Fungi. Mycological Research 111:509-547.

Høeg, O. A. 1971. Sopper. In Kulturhistoriskt Lexikon för Nordisk Medeltid 16. pp. 434-437. Allhem, Malmö.

Høeg, O. A. 1974. Planter og Tradisjon. Floraen i Levende Tale og Tradisjon $i$ Norge 1925-1973.

Universitetsforlaget, Oslo.

Huizinga, J. 1949. Homo Ludens: A Study of the PlayElement in Culture. Routledge \& Kegan Paul, London.

IFOS: Institute for Language and Folklore, Uppsala, Sweden: Folklife Records (ULMA): Document ULMA 19435 (Nargö, Estonia); ULMA 28641 (Edsele, Ångermanland).

Jaederfeldt, K. Tickboken. Sveriges mykologiska förening, Stockholm.

Kjellström, R. 2000. Samernas Liv. Carlsson, Stockholm

Klintberg, B. 1998. Kuttrasju. Folkloristiska och Kulturhistoriska Essäer. Norstedt, Stockholm.

Klintberg, B. 2012. Barnlekar i Växtriket. Rig 95:155168.

Knudsen, F. 1922. Langbold. Danske Studier 19:97126.

Knudsen F. 1932. Trak af Boldspillets Historie. Gyldendal, København.

Landstad, M. B. 1853. Norske Folkeviser. Chr. Tönsbergs Forlag, Kristiania.
Leem, K. 1767. Beskrivelse over Finmarkens Lapper. Kongel. Waysenhuses Bogtrykkerie, Kjøbenhavn.

Lévi-Strauss, C. 1962. Le Pensée Sawvage. Plon, Paris.

Lidström, I. 2017. Batting "Runders" on the Island of Runö. The Incorporation of English Bat-and-Ball Games into a Traditional Easter Celebration (or How the Shoal of "Donkom" got Its Name). Arv. Nordic Yearbook of Folk:lore 73:27-50.

Liestøl, K. 1919. Ordet Sopp i Folkevisene. Maal og Minne 1919:115-117.

Linnaeus C. 1737. Flora Lapponica. Salomonem Schouten, Amstelædami.

Linnaeus, C. 1755. Flora Svecica. L. Salvius, Stockholm.

Lönnqvist, B. 1970. Leksaker bland Finlandssvenskarna. Budkavlen 1969-1970:80-123.

Łuczaj, Ł., and M. Kujawska. 2012. Botanist and Their Childhood Memories: An Underutilized Expert Source in Ethnobotanical Research. Botanical Journal of the Linnean Society 168:334-343. DOI:10.1111/ j.1095-8339.2011.01205.x.

Maigaard, P. 1941. Battingball Games. Genus 5:57-72.

Manker, E. 1947. De Svenska Fjällapparna. Svenska Turistföreningen, Stockholm.

Manninen, I. 1933. Über die Moxibustion in der Volksmedizin der Nordvölker. Mémoires de la Société finno-ougrienne 67:256-266.

Martin, J. D. 2003. "Svá lýkr hér hverju hestaðingi": Sports and Games in Icelandic Saga Literature. Scandinavian Studies 75:25-44.

Matras, C. 1955. Soppur í Føroyskum og Sopp í Írskum. Fródskaparrit 4:15-31.

Medeiros, M. F. T. 2016. Historical Ethnobiology. In Introduction to Ethnobiology, edited by U. P. Albuquerque, R. Romeu, and N. Alves. pp. 19-24. Springer International Publishing, New York, N.Y.

Mehl, E. 1949. Notes to "Baseball in the Stone Age". Western Folklore 8:152-156.

Mendner, S. 1956. Das Ballspiel im Leben der Völker. Aschendorff, Münster.

Murberget, Västernorrland County Museum, Härnösand, Sweden: Levi Johansson Collection of Folklore (LMV-M): Manuscript LMV-M 265.

Møller, J. 1997. So i Hul og 99 andre Gamle Boldspill og Kastlege. Idrætshistorisk Værksted, Slagelse.

Nordenskiöld, E. 1912. De Sydamerikanska Indianernas Kulturbistoria. A Bonniers, Stockholm. 
NM: Nordic Museum Archives, Stockholm, Sweden: Folklife Records (EU, IFGH, M): Document EU 866 (Laxviken, Jämtland); EU 2648 (Fårö, Gotland); EU 2661 (Otterstad, Västergötland); EU 2954 (Urshult, Småland); E 7579 (Stenestad, Skåne); EU 10381 (Huddunge, Uppland); EU 10714 (Hallingeberg, Småland); EU 20893 (Frändefors, Dalsland.); EU 41254 (Revsund, Jämtland); M 7548 (Ronneby, Blekinge); IFGH 2810 (Malma, Västergötland).

Olsson, G. 2009. Leka med Växter. Svensk Botanisk Tidskrift 103:274-278.

O’Sullivan, L. 2012. Playing Ball in Greek Antiquity. Greece and Rome, Second Series 59:17-33.

Papp, N., K. Rudolf, K. Benczik, and D. Czégény. 2017. Ethnomycological Use of Fomes fomentarius (L.) Fr. and Piptoporus betulinus (Bull.) P. Karst. in Transylvania, Romania. Genetic Resources and Crop Evolution 64:101-111. DOI:10.1007/s10722-0150335-2.

Peintner, U., and R. Pöder. 2000. Ethnomycological Remarks on the Iceman's Fungi. In The Iceman and His Natural Environment, edited by S. Bortenschaler and K. Oeggl. pp. 143-150. Springer, Wien.

Ranta-Rönnlund, S. 1973. Njoalpas Söner: Berättelser om Dagligt Liv i Norr. Askild \& Kärnekull, Stockholm.

Rasmussen, T. H. 2003. The Ball: Toy of Gods and Man. In Toys in Educational and Socio-Cultural Contexts, edited by L-A. Berg, A. Nelson, and K. Svensson. pp. 155-170. SITREK, Stockholm.

Retzius, A. J. 1806. Försök til en Flora Oeconomica Sveciae Eller Swänska Wäxters Nytta och Skada i Hushålningen 1. Joh. Lundblad, Lund.

Riordan, J. 1986/1987. Folk Games and Fake Games in Soviet Times: The Case of Gorodki and Lapta. Stadion 12/13:177-181.

Rothof, L. W. 1762. Hushålls-Magasin, Första delen om Hushäls-Ämnen Til Deras nytta, bruk och skada, Beskrefne Uti Oeconomiska Föreläsningar. Möller, Skara.

Roussel, B., S. Rapior, C. Charlot, C.-L. Masson, and P. Boutié 2002. Histoire des Utilisations Thérapeutiques de l'Amadouvier (Fomes fomentarius (L. Fr.). Revue d'Histoire de la Pharmacie 90:599-614.

Säve, P. A. 1948. Svenska Lekar 1. Gotländska Lekar. Almqvist \& Wiksell, Uppsala.

Schefferus, J. 1673. Lapponia: id est, regionis Lapponum et gentis nova et verissima descriptio: in qua multa de origine, superstitione, sacris magicis, victu, cultu, negotis Lapponum. Christiani Wolffii, Francofurti.

Steen, A. 1961. Samenes Folkemedisin. Universitetsforlaget, Oslo.

Svanberg, I. 2001. Barkbåtar och Vasspipor. In Människan och Naturen: Etnobiologi i Sverige 1, edited by B. Pettersson, I. Svanberg, and H. Tunón. pp. 90-98. Wahlström \& Widstrand, Stockholm.

Svanberg I. 2007. Plant Knowledge as Indicator of Historical Cultural Contacts: Tanning in the Atlantic Fringe. In Travelling Cultures and Plants: The Ethnobiology and Ethnopharmacy of Migrations, edited by A. Pieroni and I. Vandebroek. pp. 227-244. Berghahn, Oxford.

Svanberg I. 2010. Fabulat, Plagiat och Spökuppgifter: Att Använda Berättande Källor inom Etnobiologi. In Nycklar till Kunskap: om Människans Bruk av Naturen, edited by H. Tunón and A. Dahlström. pp. 125-136. Kungl. Skogs- och Lantbruksakademien, Stockholm.

Svanberg, I. 2018. Ethnomycological Notes on Haploporus odorus and Other Polypores in Northern Fennoscandia. Journal of Northern Studies 12:73-91.

Svanberg I., Ł. Łuczaj, M. Pardo-de-Santayana, and A. Pieroni. 2011. History and Current Trends of Ethnobiological Research in Europe. In Ethnobiology, edited by E. N. Anderson, K. Adams, D. Pearsall, E. Hunn, and N. J. Turner. pp. 191-212. WileyBlackwell, Hoboken NJ.

Thurber, B. A. 2015. The Viking Ball Game. Scandinavian Studies 87:167-188. DOI:10.5406/ scanstud.87.2.0167.

Tillhagen, C. H., and N. Dencker 1949. Svenska Folklekar och Danser 1. AB Bokverk, Stockholm.

Tunón, H., and I. Svanberg 1999. Laxatives and the Ice Man. The Lancet 353:925-926. DOI:10.1016/ S0140-6736(05)79939-6

Turner, N.J. 1998. Plant Technology of First People in British Columbia. University of British Columbia Press, Vancouver.

Unger, C. R. 1860. Karlamagnus Saga ok Kappa Hans: Fortællinger om Keiser Karl Magnus og Hans Jævninger: i Norsk Bearbeidelse Fra Det Trettende Aarbundrede. H.J. Jensen, Christiania.

Vold Halvorsen, K-B. 1983. Litt om Leiketøy i Eldre Tid. By og Bygd 29:79-92. 
Wessman, V. E. V. 1962. Finlands svenska folkdiktning 8: Lekar och spel. Svenska Litteratursällskapet i Finland, Helsingfors.

Yamin-Pasternak, S. 2011. Ethnomycology. Fungi and Mushrooms in Cultural Entanglements. In Ethnobiology, edited by E. N. Anderson, K. Adams,
D. Pearsall, E. Hunn, and N. J. Turner. pp. 213230. Wiley-Blackwell, Hoboken, NJ.

Zarger, R. K., and J. R. Stepp. 2004. Persistence of Botanical Knowledge among Tzeltal Maya Children. Current Anthropology 45:413-418.

DOI:10.1086/420908. 